\begin{tabular}{c} 
Volume and Issues Obtainable at Center for Sustainability Research and Consultancy \\
Journal of Accounting and Finance in Emerging Economies \\
ISSN: $2519-0318$ \& ISSN (E): $2518-8488$ \\
Volume 7: Issue 4 December 2021 \\
CSR \\
Journal homepage: $\underline{\text { www.publishing.globalcsrc.org/jafee }}$ \\
\hline
\end{tabular}

\title{
Impact of Service Quality and Price Fairness on Consumer Loyalty: The Moderating Role of Information Literacy
}

*Muhammad Adnan, Azteca University (UA), Mexico, Universidad Central de Nicaragua, Republic of Nicaragua (North America), National College of Business Administration \& Economics (NCBA\&E) Lahore, Multan Sub-campus, Pakistan

Samia Zarrar, National College of Business Administration \& Economics (NCBA\&E) Lahore, Multan Subcampus, Pakistan

Kamran Zafar, National College of Business Administration \& Economics (NCBA\&E) Lahore, Multan Subcampus, Pakistan

*Corresponding author's email address: dr.adnanmalik1989@gmail.com

\section{ARTICLE DETAILS}

\section{History}

Revised format: Nov 2021

Available Online: Dec 2021

\section{Keywords}

Service Quality, Price

Fairness, Consumer Loyalty,

Information Literacy, PLS,

Hotel Industry

JEL Classification

$M 1, M 12$

\section{ABSTRACT}

Purpose: Using data from 200 hotel guests in Multan, Pakistan, this research aims to evaluate the influence of service quality and pricing fairness on consumer loyalty while moderating the role of information literacy.

Design/Methodology/Approach/Findings: The findings are estimated using partial least square (PLS). The variables service quality, pricing justice, and information literacy are all positively and substantially connected to customer loyalty, according to PLS estimations. Because the link between service quality and customer loyalty is statistically significant, the results of the moderated regression demonstrate that information literacy positively moderates it. On the other hand, while the link between price fairness and customer loyalty is statistically significant, the variable information literacy acts as a negative moderator.

Implications/Originality/Value: Hotel management are advised to invest in and increase the quality of service. Managers must maintain control of all activities related to the concept of quality from the bottom to the top of their business.

(C) 2021, The authors, under a Creative Commons Attribution-

NonCommercial 4.0

Recommended citation: Adnan, M., Zarrar, S. and Zafar, K. (2021). Impact of Service Quality and Price Fairness on Consumer Loyalty: The Moderating role of Information Literacy. Journal of Accounting and Finance in Emerging Economies, 7(4), 869-883.

\section{Introduction}

\section{Background of the Study}

In today's current, dynamic market environment, service quality has become a hot issue in service analysis. It is almost impossible for a business to succeed without establishing customer pleasure and brand loyalty (Panda, 2003). The focus of today's discussion is on the impact of operational quality on the 
profit and financial outcomes of the company. The relationship between service quality and benefit is yet unknown. Customer happiness and loyalty retention are challenging to achieve.

Because of the intense rivalry and the adversarial mood of natural components, service quality has become a straightforward advertising method for businesses. This demonstrates how critical it is for businesses to improve service quality in order to ensure their long-term viability and development, as it will enable them to deal with the dangers they face in today's competitive marketplaces (Joudeh \& Dandis, 2018). Customer loyalty, according to Naik et al. (2010), may be impacted by a variety of factors. Service quality, rather than product excellence, is appreciated and sought after. Customers' faith in service is not only based on service outputs, but it is also maintained as long as the service is provided. To begin, consider how employees interact and behave throughout the transaction process. Furthermore, strong service quality will be considered as a measure of ensuring the company's survival and development.

The company's reputation would be enhanced by high service quality. Services are a developing process of continual customer-service encounters that include a variety of intangible activities supplied as premium solutions to customer difficulties, as well as physical and financial instruments and all other important framework pieces involved in the supply of these services (Gronroos, 2004). Customer loyalty and quality of service are critical principles that businesses must consider in order to stay focused on their company and develop it. Companies must evaluate how to assess these structures from the perspective of consumers, with a clear end goal in mind, in order to fully comprehend and meet their expectations. The importance of service quality is recognized since it leads to increased customer loyalty, profit, lower costs, customer commitment, and maintenance (Joudeh \& Dandis, 2018). According to Chingang and Lukong, the entire assessment of service by consumers is the quality of service (2010).

Customer loyalty is seen to be a construct made up of both the customer's attitude and behaviors. The consumer's attitude reflects principles such as the desire to repurchase or buy additional goods or services from the same brand, the ability to refer the company to others, the demonstration of such loyalty to the company by demonstrating an aversion to switching to a competitor, and the willingness to pay a higher price (Cronin \& Taylor, 2007). Consumer loyalty's behavioral component, on the other hand, is the actual recurrent purchase of goods or services, which comprises buying more and different items or services from the same firm, endorsing the company to others and indicating the probability of the brand's longterm preference. Consumer loyalty, it might be assumed, symbolizes the anticipated activities linked with the product, service, or company. Customer happiness is seen as a critical component of long-term market expansion (Donnelly, 2009).

This research seeks to evaluate the influence of service quality on customer loyalty in the hotel business of Pakistan, mitigating the effect of information literacy, after providing theoretical correlations between service quality and consumer loyalty. The hotel sector has grown to be the most well-known on the planet. In the hotel industry, restaurants, rooms, and health clubs are no longer considered luxury facilities. These services are a necessary element of many people's everyday life. The hotel industry's services have changed dramatically during the last two decades, moving from traditional to contemporary conditions. Passenger growth has been encouraged by the supply and demand for hotel sector services, and the industry is becoming more competitive. The most pressing challenge confronting the hotel sector today is the growing volume and pace of competition (Saleem \& Raja, 2014).

\section{Significance of the Study}

Hotel executives feel that the greatest way to make income is to please consumers. According to the bulk of empirical research, just delighting clients does not guarantee that they will remain with you or utilize your services in the future. In terms of corporate success, only customer loyalty is more crucial than customer satisfaction. The price paid by hotels, on the other hand, is a significant factor that may have a favorable or negative influence on marketing activities. The goal of this study is to see how service quality and pricing justice affect customer loyalty in the Pakistani hotel industry. The hotel industry is a 
fast-increasing sector across the globe, and no one has given much attention to performing research on it until lately. As a consequence, we investigate the influence of service quality and pricing fairness on customer loyalty in the Pakistan hotel industry, as well as the moderating function of information literacy.

\section{Literature Review}

This section provides the definitions and literature on theoretical link between variables.

\section{Service Quality}

A service is an economic activity that provides customers with additional value and benefits at certain times and places by creating a desired change in or on behalf of the service receiver. Despite the fact that the process is related to a physical product, the performance is fleeting, often intangible, and seldom results in ownership of any of the production factors (Lovelock \& Wirtz, 2004). Meeting specified expectations, on the other hand, demonstrates to the customer the product or service's worth (or quality), including its economic value, safety, reliability, and maintainability.

According to Parasuraman et al. (1988), service quality is defined as the gap between customer demands and service experiences in order to gain a strategic advantage. This implies that delivering excellent service requires consistently meeting client expectations, which may be assessed by determining if the delivery of perceived service meets, exceeds, or fails to meet customer expectations.

\section{Consumer Loyalty}

Consumer loyalty has been a significant idea in marketing during the past decade, especially in the quickly increasing area of customer relationship management. Customer loyalty may be described in two different ways. To begin with, loyalty is a mindset. Different emotions determine a person's eventual association with a product, service, or organization. These feelings define an individual's (purely cognitive) level of loyalty. Behavioral loyalty is the second kind of loyalty. Loyalty activities include things like continuing to purchase services from the same supplier, expanding the size and/or reach of a relationship, or making a proposal (Yi, 1990). Neal (1999) defined customer loyalty as the percentage of times a buyer selects the same product or service in a certain category compared to the entire quantity of transactions done in that category by the consumer, assuming that other.

\section{Price Fairness}

Price fairness, according to Xia et al. (2004), is the customer's assessment of whether the gap (or lack thereof) between a seller's price and the price of a similar party is reasonable, justified, or justifiable. Customers, on the other hand, sense market injustice since they pay greater prices than competitors. Price is one of the most important parts of the marketing mix, as well as other marketing mix elements, and has a significant impact on customer purchase choices (Kotler et al., 2012).

\section{Information Literacy}

Information literacy is defined as the ability to locate, examine, critically evaluate, and use information to solve problems in a number of contexts, including school-based independent project work. We think that the emphasis on locating and choosing information sources in various information literacy programs reflects a long history of library use instruction that has primarily focused on sources, search tactics, and information assessment (Bawden, 2001).

\section{Relationship between Service Quality and Consumer Loyalty}

Fida et al. (2020) discovered that respondents gave a "Agreement" answer on average in the five domains of tangibles, responsiveness, dependability, assurance, and empathy. The correlation data demonstrated a substantial relationship between the three variables: degree of service, customer satisfaction, and customer loyalty. Kumar et al. (2019) discovered that quality offers in the telecoms industry had not only a positive but also a significant impact on customer pleasure and loyalty. The impact of service quality on customer loyalty was investigated by Ajmal et al. (2018). In Pakistan's banking industry, the research shed light on the impact of service quality on consumer satisfaction. Customer loyalty has a supporting and significant 
link with components of service quality such as tangibility, empathy, and certainty, according to the study's results. According to Dubey and Srivastava (2016), the consistency of the service has a significant and positive impact on the preservation of client relationships and satisfaction. Across the four antecedents of service efficiency, tangibility and assurance have a considerable and favorable influence on the management of customer relationships, while tangibility has a big impact on customer loyalty.

Firend and Abadi (2014) looked at the impacts of service efficiency, confidence, and customer perceived value on customer loyalty in the Malaysian business sector. The research found that there was a positive association between service quality and confidence, service quality and perceived value, trust and consumer loyalty, and perceived value and customer loyalty. According to the findings, customer service, confidence, and perceived value are all seen to be antecedents of client loyalty. Poku et al. (2013) investigated how service quality influences customer loyalty in Ghana. The results confirmed the existence of a clear correlation between customer satisfaction and loyalty. Because consumers have grown less satisfied with it and are more inclined to take it for granted in their search for development, "tangibility" does not play a vital role for all hotels in growing consumer contentment. According to the findings, hotel categorization may not be only based on physical factors, but rather on a full service that provides value for money and influences customer loyalty. In Penang, Malaysia, Kheng et al. (2010) investigated the impact of service quality on customer loyalty among bank clients, with customer satisfaction mediating these factors. The findings showed that improving service quality might boost consumer loyalty. The service efficiency elements that played a crucial influence in this computation were reliability, empathy, and assurance. The findings revealed that the bank was seen well by the general public, but that there was still potential for improvement.

\section{Relationship between Price Fairness and Consumer Loyalty}

Price perceptions have long been examined in several fields of social science, such as marketing and economics. It is commonly understood that a client's pricing experience may be assessed in two ways: it either increases or decreases customer loyalty, which leads to useful behaviors (Leinsle et al., 2018). For example, Konuk (2018) looked at the impact of pricing expectations on customer loyalty and buying behavior. According to the results of the research, people's concept of price justice has a favorable impact on their willingness to pay more for satisfying experiences. The lower the price perception, the lower the commodity perception of sacrifice, according to Bei \& Chiao (2001). Customers may be more comfortable with their comprehension of expenses and the entire transaction if this is done. This suggests that monetary prices or price expectations do not boost pleasure naturally. Customers often correlate prices with service efficiency based on the idea of equality, resulting in consumer happiness or disappointment.

Susanti (2019) used customer satisfaction in budget hotels in East Java to investigate the influence of service quality and perceived price fairness on consumer loyalty. The outcomes of the research show that, first and foremost, the quality of service has a positive and significant influence on customer loyalty. Second, customers' perceptions of pricing fairness have a significant impact on their loyalty. Second, client retention has a significant and positive influence on customer engagement. Fourth, service efficiency has a favorable and substantial influence on client loyalty via customer satisfaction. Fifth, customer satisfaction's perception of pricing fairness has a favorable and substantial influence on customer loyalty. Cakici et al. (2019) looked at the relationships between perceived price justice, satisfaction, revisit intention, and loyalty, emphasizing on the role of revisit intention as a mediating factor in the relationship between perceived price justice, contentment, and loyalty. Pricing justice and satisfaction have a good influence on restaurant customers' return intention, and revisit intention has a positive impact on restaurant customers' loyalty, according to the findings of structural equation modelling. According to the data, whereas revisit intention completely mediators the influence of price justice and loyalty, it only partly mediates the effect of satisfaction and loyalty.

\section{Relationship among Service Quality, Price fairness, Customer loyalty \& Information literacy}


Information literacy is defined as the ability to locate, examine, critically evaluate, and use information to solve problems in a number of contexts, including school-based independent project work. We think that the emphasis on locating and choosing information sources in various information literacy programs reflects a long history of library use instruction that has primarily focused on sources, search tactics, and information assessment (Bawden, 2001). This makes it possible for researchers to be lifelong learners. Only a few sectors of study have employed this powerful method that not only differentiates unauthentic material from authentic knowledge. The goal of this study is to get the most out of this holistic approach to learning in the area of customer service. It is estimated that information literacy would help consumers grasp the sensitive nature of service quality while also assisting service providers in making their clients aware of the aspects of their products (tangible or intangible).

Educating customers about service quality and pricing fairness helps service providers in removing misconceptions and confusions regarding service quality. It automates the conversion of a retained client into a loyal customer in some way. Once a consumer is completely informed about all aspects of pricing fairness and service quality, he or she is no longer necessary to be attended to from the beginning on each transaction. An information literate client may do a self-analysis for the comparative amount spent on a given product and its perceived value if there is a price increase or change.

\section{Conceptual Framework}

Following the literature review this study developed a theoretical framework presented in Figure 1. Figure 1 shows the theoretical model of this research. The dependent variable used in a study is customer loyalty while independent variables are price fairness and service quality. The moderation variable is information literacy.

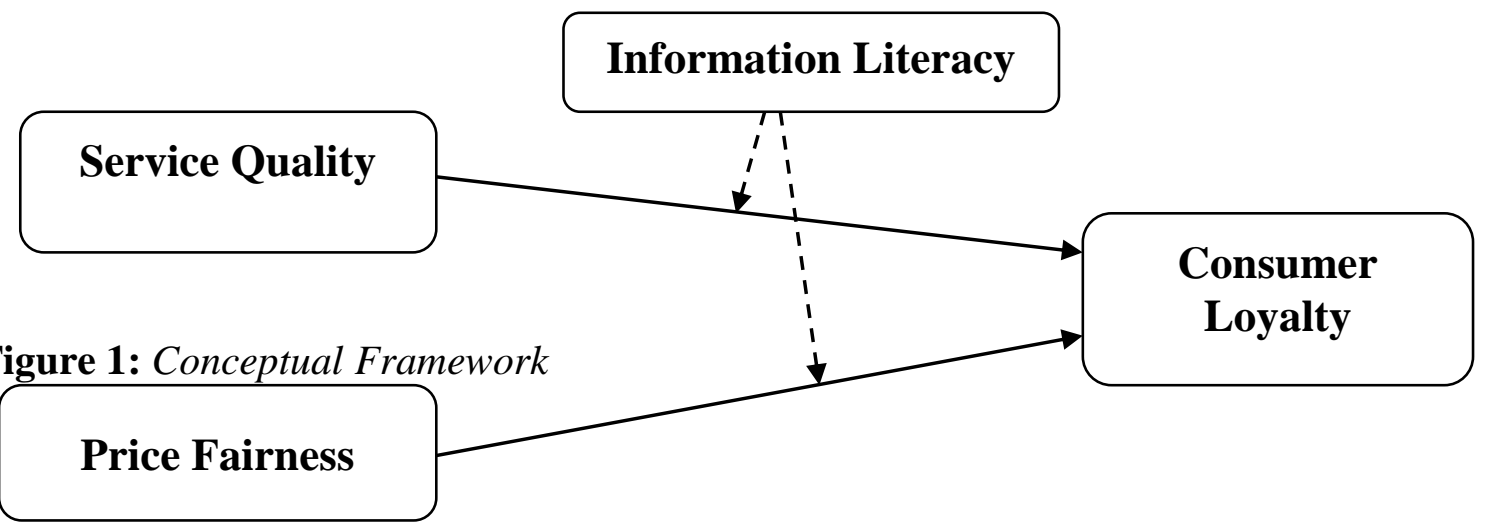

\section{Methodology}

\section{Population and Sampling Design}

The customers of all operational top category outlets existing in the hotel industry (food and beverage) of Multan city are included as the population in the study. The data of 200 customers of hotels in Multan city are collected by using non-probability convenient sampling technique. Sample size will be 10\% of hotel industry's consumers in Multan. This sampling ratio was used by (Kang, Stein, Hoe, Lee 2012), in a similar study. The amount of ten hotels (food and beverage) is selected for data collection by using a convenient sampling technique.

\section{Model Specification}

Two models are developed to analyze the impact of service quality and price fairness on consumer loyalty by moderating the impact of information literacy. 
Model-I: Examines the Impact of Service Quality, Price Fairness, and Information Literacy on Consumer Loyalty

$\mathrm{CONL}_{\mathrm{i}}=\beta_{\mathrm{o}}+\beta_{1} \mathrm{SQL}+\beta_{2} \mathrm{PRF}+\beta_{3} \mathrm{INFL}+u_{i}$

Where;

$\mathrm{CONL}=$ Consumer loyalty

$\mathrm{SQL}=$ Service quality

$\mathrm{PRF}=$ Price fairness

INFL $=$ Information literacy

$\mathrm{u}_{\mathrm{i}}$ : error term

Model-II: Examines the Impact of Service Quality, and Price Fairness on Consumer Loyalty: Moderating the Role of Information Literacy

$\mathrm{CONL}_{\mathrm{i}}=\beta_{\mathrm{o}}+\beta_{1} \mathrm{SQL}+\beta_{2} \mathrm{PRF}+\beta_{3} \mathrm{INFL}+\beta_{4} \mathrm{SQL} * \mathrm{INFL}+\beta_{5} \mathrm{PRF} * \mathrm{INFL}+u_{i}$

Where;

CONL $=$ Consumer loyalty

$\mathrm{SQL}=$ Service quality

$\mathrm{PRF}=$ Price fairness

$\mathrm{INFL}=$ Information literacy

SQL*INFL= Interaction term of service quality and information literacy

PRF*INFL= Interaction term of price fairness and information literacy

$\mathrm{u}_{\mathrm{i}}$ : error term

Table 1: Description of Variables

\begin{tabular}{|c|c|}
\hline Description of Variables & \\
\hline Dependent Variable & \\
\hline Consumer loyalty & $\begin{array}{l}\text { Measure by five-point Lickert scale it consists of six statements that } \\
\text { were also used by Dehghan \& Shahin, (2011) }\end{array}$ \\
\hline
\end{tabular}

\section{Moderating Variable}

INFL Information literacy Measured with a five-point Lickert scale that was developed by

Pinto, (2010). Information literacy consists of five statements

\begin{tabular}{lll}
\hline Independent Variables & \\
\hline SQL & Service quality & $\begin{array}{l}\text { Measured with a 5-point Lickert scale that consists of eight items } \\
\text { that were developed by Parasuraman et al. (1988). }\end{array}$ \\
\hline PRF & Price fairness & $\begin{array}{l}\text { Measured with a five-point Lickert scale that consists of four } \\
\text { statements and also used by Darke \& Dahl, (2003). }\end{array}$
\end{tabular}

\section{Hypothesis Development}

Based on the literature the following research hypotheses are developed:

$\mathbf{H}_{\mathbf{1}}$ : The impact of service quality on consumer loyalty is positive.

$\mathbf{H}_{2}$ : The impact of information literacy on consumer loyalty is positive.

$\mathbf{H}_{3}$ : The impact of price fairness on consumer loyalty is positive

$\mathbf{H}_{4}$ : Information literacy moderates the relationship between service quality and consumer loyalty

$\mathbf{H}_{5}$ : Information literacy moderates the relationship between price fairness and consumer loyalty

\section{Methodological Issues}

Different econometric techniques are applied to attain the objectives of the study. Confirmatory factor analysis (CFA) is conducted to observe the measurement model which consists of Cronbach's Alpha, rho_A, composite reliability and average variance extracted (AVE). The Cronbach's Alpha value should be greater than 0.70 . The value of composite reliability should be greater than 0.60 (Fornell, \& Larcker, 1981) while the value of average variance extracted should be greater than 0.50 (Hair et al. 2014). Partial 
least square method is used to assess the impact of service quality and price fairness on consumer loyalty by moderating the role of information literacy. When using PLS-SEM, researchers must go through a multi-stage procedure that includes defining the inner and outer models, collecting and examining data, estimating the model, and evaluating the findings (Hair et al. 2014).

\section{Descriptive Analysis}

This section explains the descriptive statistics of variables in terms of minimum value, maximum value, the mean and standard deviation of a variable. Table 2 demonstrates the descriptive statistics of variables.

Table 2: Descriptive Statistics

\begin{tabular}{lllllll}
\hline Variables & Minimum & Maximum & Mean & S.D & Kurtosis & Skewness \\
\hline AGE & 23 & 52 & 35.01 & 5.636 & 0.661 & 3.731 \\
INC & 20000 & 95000 & 41343 & 13475 & 1.795 & 6.665 \\
EDU & 10 & 18 & 15.59 & 1.436 & -1.227 & 5.906 \\
CONL & 13 & 30 & 24.51 & 3.780 & -0.880 & 2.733 \\
SQL & 11 & 40 & 32.16 & 7.177 & -1.423 & 3.931 \\
INFL & 11 & 30 & 23.97 & 4.761 & -1.220 & 3.510 \\
PRF & 6 & 20 & 15.65 & 2.842 & -1.228 & 4.306 \\
\hline
\end{tabular}

Source: Author's Calculations

\section{Correlation Analysis}

Table 3 shows that consumer loyalty is positively correlated with service quality $(0.856)$, information literacy (0.891), and price fairness (0.668).

\begin{tabular}{lllll} 
& \multicolumn{2}{c}{ Table 4.29: Correlation Matrix } & PRF \\
\hline Variables & CONL & SQL & INFL & \\
\hline SQN & 1 & & & \\
\hline INFL & $0.856^{* *}$ & 1 & 1 & 1 \\
\hline PRF & $0.891^{* *}$ & $0.912^{* *}$ & $0.627^{* *}$ & \\
\hline
\end{tabular}

Source: Author's Calculations

\section{Measurement Model}

Measurement model consists of confirmatory factor analysis and factor loadings.

\section{Construct Reliability and Validity}

Confirmatory factor analysis (CFA) is conducted to observe the measurement model which consists of Cronbach's Alpha, rho_A, composite reliability and average variance extracted (AVE). The Cronbach's Alpha value should be greater than 0.70 and it is found that alpha value of all the variables is greater than 0.70. The value of composite reliability should be greater than 0.60 (Fornell \& Larcker, 1981) while the value of average variance extracted should be greater than 0.50 (Hair et al. 2014). The outcomes show that the value of composite reliability and average variance extracted is above the threshold levels. So we can conclude that the data used in a study for analysis is reliable.

Table 4: Construct Reliability and Validity

\begin{tabular}{llllll}
\hline Variables & $\begin{array}{l}\text { Cronbach's } \\
\text { Alpha }\end{array}$ & rho_A & Composite Reliability & $\begin{array}{l}\text { Average } \\
\text { Extracted (AVE) }\end{array}$ & Variance \\
\hline CONL & 0.811 & 0.844 & 0.875 & 0.64 \\
\hline INFL & 0.905 & 0.914 & 0.929 & 0.725 \\
\hline PRF & 0.758 & 0.819 & 0.859 & 0.673 \\
\hline SQL & 0.953 & 0.958 & 0.961 & 0.755 \\
\hline
\end{tabular}

Variables Description

CONL: Consumer Loyalty, INFL: Information Literacy, PRF, Price Fairness,

SQL: Service Quality

\section{Factor Loading}

Source: Author's Calculations

Factor loadings indicate that items of a construct are highly correlating with each other. The value of factor loading should be greater than 0.60 (Hair et al. 2007). If the value of factor loading is found to be 
less than 0.60 it indicates that items of one construct are correlating with items of other construct and not measuring the desired construct. This situation is considered as an issue and not acceptable. If items have factor loading less than 0.60 it should be excluded. Table 5 presents the factor loadings. Outcomes show that most of the items have factor loading value greater than 0.60 but few have value less than 0.60 . So that items having factor loading value less than 0.60 is excluded from the study.

Table 5: Factor Loading

\begin{tabular}{|c|c|c|}
\hline Variables & Factor Loading & Result \\
\hline \multicolumn{3}{|c|}{ Consumer Loyalty } \\
\hline $\begin{array}{l}\text { I use products/services from the company } \\
\text { because it is the best choice for me }\end{array}$ & 0.572 & Rejected \\
\hline $\begin{array}{l}\text { I intend to keep buying the products/services } \\
\text { from the company }\end{array}$ & 0.722 & Accepted \\
\hline $\begin{array}{l}\text { The company is different from competing } \\
\text { brands }\end{array}$ & 0.782 & Accepted \\
\hline $\begin{array}{l}\text { I say positive things about the company to } \\
\text { other people }\end{array}$ & 0.741 & Accepted \\
\hline $\begin{array}{l}\text { I have a positive emotional relation to the } \\
\text { company I have chosen and I feel attached to } \\
\text { it }\end{array}$ & 0.862 & Accepted \\
\hline $\begin{array}{l}\text { I consider myself to be a loyal patron of the } \\
\text { company }\end{array}$ & 0.509 & Rejected \\
\hline
\end{tabular}

\begin{tabular}{|c|c|c|}
\hline \multicolumn{3}{|c|}{ Information Literacy } \\
\hline I use printed sources of information & 0.890 & Accepted \\
\hline I enter and use automated catalogues & 0.826 & Accepted \\
\hline $\begin{array}{l}\text { I consult and use electronic sources of } \\
\text { primary information }\end{array}$ & 0.768 & Accepted \\
\hline $\begin{array}{l}\text { I use electronic sources of secondary } \\
\text { information }\end{array}$ & 0.510 & Rejected \\
\hline I search for and retrieve internet information & 0.903 & Accepted \\
\hline I use printed sources of information & 0.807 & Accepted \\
\hline \multicolumn{3}{|c|}{ Price Fairness } \\
\hline The price I paid was fair. & 0.727 & Accepted \\
\hline The price I paid was justified. & 0.513 & Rejected \\
\hline I am happy with my purchase decision. & 0.846 & Accepted \\
\hline The price I paid was honest & 0.843 & Accepted \\
\hline
\end{tabular}




\section{Service Quality}

\begin{tabular}{llc}
\hline The hotel has modern looking equipment & 0.890 & Accepted \\
\hline The hotel's physical facilities are visually & 0.926 & Accepted \\
appealing & & Accepted \\
\hline The hotel's employees are neat-appearing & 0.807 & Accepted \\
\hline Materials associated with the service are & 0.867 & Accepted \\
visually appealing at the hotel & 0.873 & Accepted \\
\hline The hotel performs the service right the first & & 0.903 \\
time & & Accepted \\
\hline $\begin{array}{l}\text { The hotel provides its services at the time it } \\
\text { promises to do so }\end{array}$ & 0.833 & Accepted \\
\hline The behavior of employees of the hotel instills & & 0.847 \\
confidence in customers & & \\
\hline Employees of the hotel understand your & & \\
specific needs & & \\
\hline
\end{tabular}

\section{Structural Equation Modeling}

Source: Author's Calculations

Table 6 presents the Partial Least Square (PLS) estimates of impact of service quality and price fairness on consumer loyalty: moderating the role of information literacy. The dependent variable used in a model is consumer loyalty (CONL), and independent variables are service quality (SQL), price fairness (PRF), while moderator variable is information literacy (INFL). The outcomes explores that the variables service quality, price fairness, and information literacy positively and significantly related to the consumer loyalty. The value of $\mathrm{R}^{2}$ is found to be 0.776 , it explores that the variation in dependent variable (consumer loyalty) due to independent variables is 77.6 percent while lasting 22.4 percent is due to the other factors that are not added in a model.

Table 6: PLS Estimates of Impact of Service Quality \& Price Fairness on Consumer Loyalty

\begin{tabular}{lcccccc}
\hline \multicolumn{1}{c}{ Variables } & $\begin{array}{c}\text { Original } \\
\text { Sample }\end{array}$ & $\begin{array}{c}\text { Sample } \\
\text { Mean }\end{array}$ & $\begin{array}{c}\text { Standard } \\
\text { Deviation }\end{array}$ & $\begin{array}{c}\text { T } \\
\text { Statistics }\end{array}$ & P-Values & Results \\
\hline SQL $\rightarrow$ CONL & 0.312 & 0.318 & 0.101 & 3.099 & 0.002 & Supported \\
\hline PRF $\rightarrow$ CONL & 0.106 & 0.100 & 0.058 & 1.828 & 0.068 & $\begin{array}{c}\text { Partially } \\
\text { supported }\end{array}$ \\
\hline INFL $\rightarrow$ CONL & 0.508 & 0.508 & 0.112 & 4.548 & 0.000 & Supported \\
\hline$R^{2}$ & & & 0.776 & &
\end{tabular}

\section{Moderation Analysis}

Source: Author's Calculations

Table 7 presents the PLS estimates of impact of service quality and price fairness on consumer loyalty: moderating the role of information literacy. The interaction term of service quality and information literacy (SQL*INF), price fairness and information literacy (PRF*INFL) is added into the model. The outcomes of the moderated regression show that information literacy positively moderates the relationship between service quality and consumer loyalty as the association is found to be statistically significant $($ Coefficient $=0.269$, Prob. $=0.000)$. The fourth hypothesis of the study "information literacy moderates the relationship between service quality and consumer loyalty" is accepted. On the contrary the variable information literacy negatively moderates the relationship between price fairness and consumer loyalty as the association is found to be statistically significant (Coefficient $=-0.121$, Prob. $=0.002$ ). The fifth 
hypothesis of the study "information literacy moderates the relationship between price fairness and consumer loyalty" is accepted. The value of $\mathrm{R}^{2}$ is found to be 0.805 , it explores that the variation in dependent variable (consumer loyalty) due to independent variables is 80.5 percent while lasting 19.5 percent is due to the other factors that are not added in a model. The change in $\mathrm{R}^{2}$ is found to be 0.029 , it shows small size effect.

\begin{tabular}{|c|c|c|c|c|c|c|}
\hline Variables & $\begin{array}{c}\text { Original } \\
\text { Sample }\end{array}$ & $\begin{array}{c}\text { Sample } \\
\text { Mean }\end{array}$ & $\begin{array}{l}\text { Standard } \\
\text { Deviation }\end{array}$ & $\begin{array}{c}\text { T- } \\
\text { Statistics }\end{array}$ & $\begin{array}{c}\text { P- } \\
\text { Values }\end{array}$ & Results \\
\hline $\begin{array}{l}\text { SQL*INFL - } \\
>\text { CONL }\end{array}$ & 0.269 & 0.262 & 0.052 & 5.150 & 0.000 & Supported \\
\hline $\begin{array}{l}\text { PRF*INFL - } \\
>\text { CONL }\end{array}$ & -0.121 & -0.124 & 0.041 & 2.975 & 0.003 & Supported \\
\hline $\mathbf{R}^{2}$ & & & & 0.805 & & \\
\hline$\Delta \mathbf{R}^{2}$ & & & & 0.029 & & \\
\hline
\end{tabular}

Source: Author's Calculations

An alternative way to observe the moderation analysis by simply look at the sloop analysis that visualize two-way interaction effect. Figure 2 shows the simple slope analysis to test the moderation association. The three lines in the figure show the relationship between service quality and information literacy. The middle lines in the figure shows the moderator variable information literacy. Figure shows that higher information literacy stronger the relationship between service quality and consumer loyalty while lower information literacy weaker the relationship between service quality and consumer loyalty. This relationship is found to be positive.

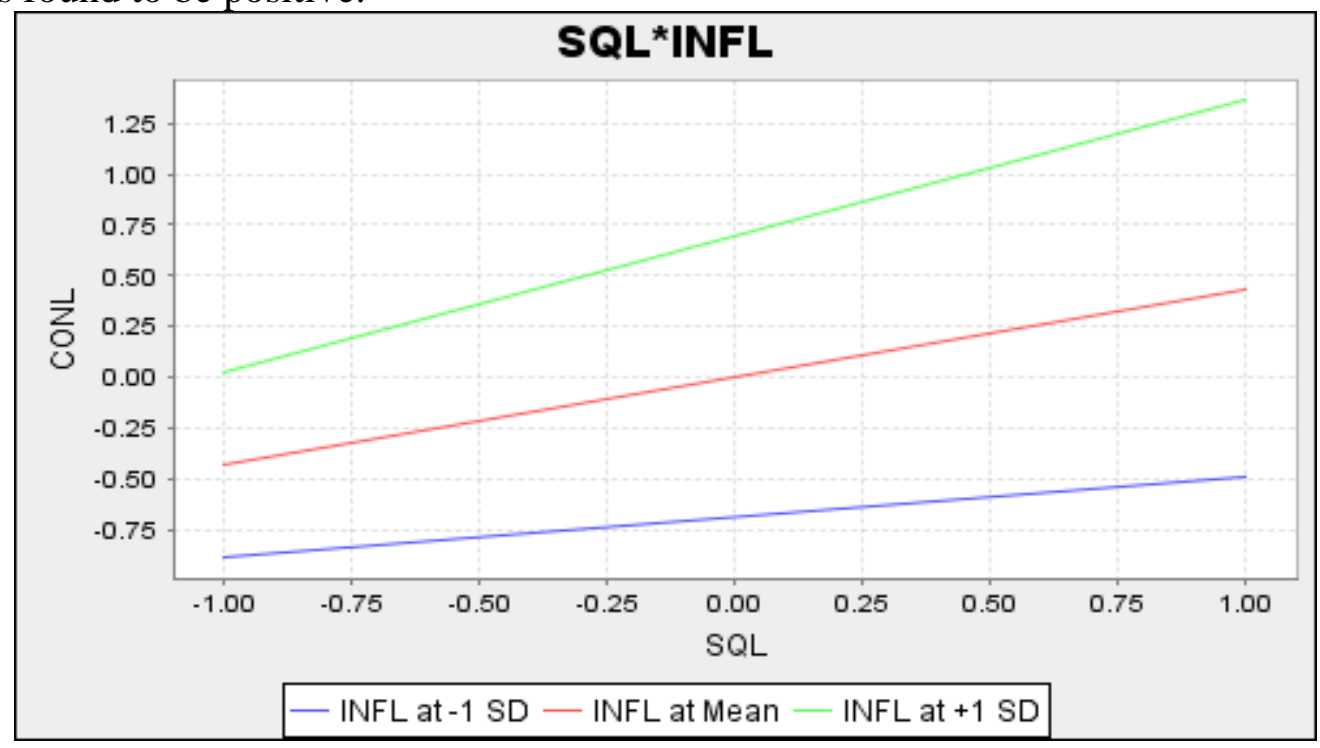

Figure 2: Slope Plot Analysis

Source: Author's Calculations

Figure 3 shows the simple slope analysis to test the moderation association. The three lines in the figure shows the relationship between price fairness and information literacy. The middle line in the figure shows the moderator variable information literacy. Figure shows that higher information literacy lead to weaker the relationship between price fairness and consumer loyalty while lower information literacy lead to stronger the relationship between price fairness and consumer loyalty. This relationship is found to be negative. 


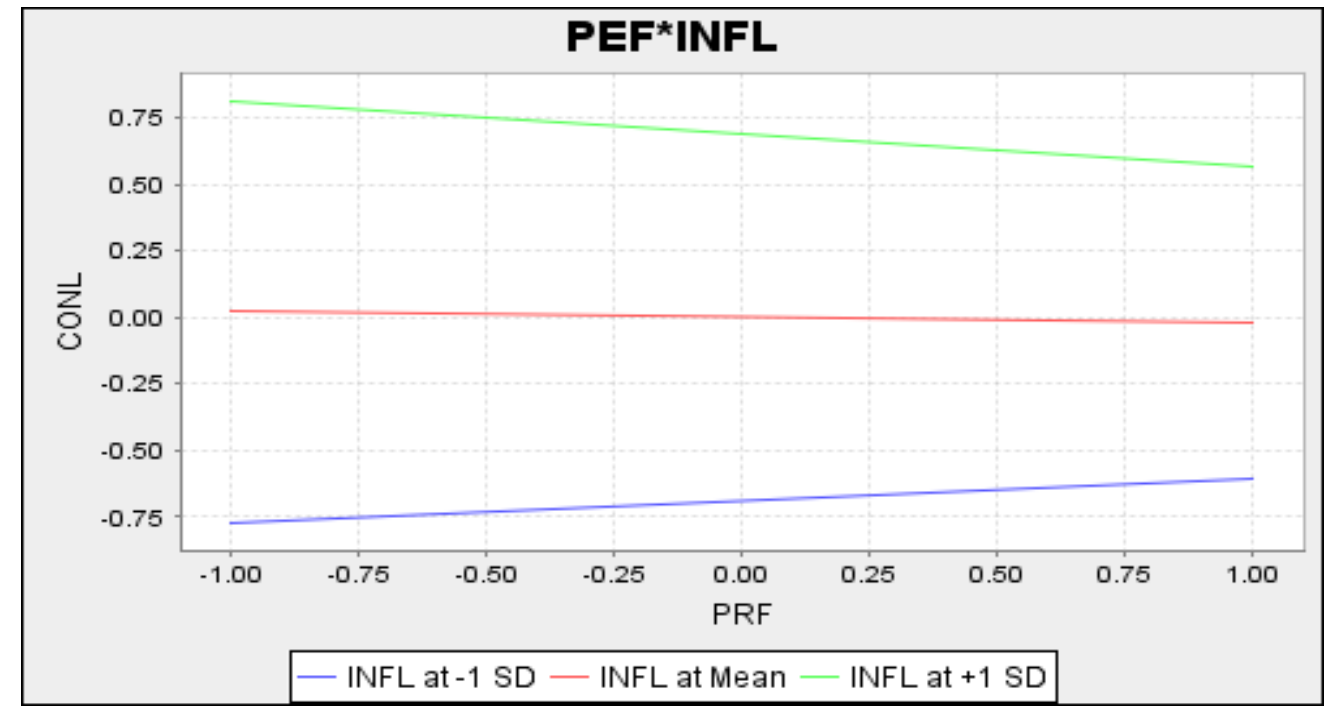

Figure 3: Slope Plot Analysis

Source: Author's Calculations

\section{Hypothesis-wise Discussion}

\section{$\mathrm{H}_{1}$ : The impact of service quality on consumer loyalty is positive}

It is found that service quality is positively and significantly $(t-s t a t=3.099$, Prob. $=0.002)$ associated to the consumer loyalty so that the first hypothesis of the study "there is positive relationship between service quality and consumer loyalty" is accepted. Good service quality would represent a good reputation for the company. Services are an evolving process of ongoing customer-service encounters consisting of a range of intangible activities that are offered as premium solutions to customer issues, including physical and financial tools and all other valuable framework elements involved in the provision of these services (Gronroos, 2004). So that consumers become more loyal to the companies that provide good service quality. These outcomes are also verified in the studies of Fida et al. (2020); Safi \& Awan (2018); Kumar (2017); Poku et al. (2013).

\section{$\mathrm{H}_{3}$ : The impact of price fairness on consumer loyalty is positive}

The variable price fairness is also found to be positively $(t-s t a t=1.828$, Prob. $=0.068)$ associated to the consumer loyalty. The second hypothesis of the study "there is positive relationship between price fairness and consumer loyalty" is accepted. If consumers perceived that the price charge by companies is fair so they become more loyal to the products of the companies. These outcomes are also found in the studies of Susanti (2019); Nazari et al. (2014); Yaqub et al. (2019).

\section{$\mathbf{H}_{3}$ : The impact of information literacy on consumer loyalty is positive}

The variable information literacy is also found to be positively and significantly $(t-s t a t=4.548$, Prob. $=$ 0.000 ) associated to the consumer loyalty. The third hypothesis of the study "there is positive relationship between information literacy and consumer loyalty" is accepted. If consumers have full information regarding the product quality in comparison to the other companies they may choose high quality product companies so that consumers become more loyal with companies having more information literacy about that company.

\section{$\mathbf{H}_{4}$ : Information literacy moderates the relationship between service quality and consumer loyalty} The moderator variable information literacy positively moderates the relationship between service quality and consumer loyalty as the association is found to be statistically significant (Coefficient $=0.269$, Prob. $=$ 0.000). The fourth hypothesis of the study "information literacy moderates the relationship between service quality and consumer loyalty" is accepted.

$H_{5}$ : Information literacy moderates the relationship between price fairness and consumer loyalty The moderator variable information literacy negatively moderates the relationship between price fairness 
and consumer loyalty as the association is found to be statistically significant $($ Coefficient $=-0.121$, Prob. $=0.002$ ). The fifth hypothesis of the study "information literacy moderates the relationship between price fairness and consumer loyalty" is accepted

Table 8: Research Hypothesis

\begin{tabular}{clc}
\hline Hypothesis & \multicolumn{1}{c}{ Description of Hypothesis } & Result \\
\hline $\mathbf{H}_{\mathbf{1}}$ & $\begin{array}{l}\text { The impact of service quality on consumer loyalty is } \\
\text { positive }\end{array}$ & Accepted \\
\hline $\mathbf{H}_{2}$ & $\begin{array}{l}\text { The impact of information literacy on consumer loyalty is } \\
\text { positive }\end{array}$ & Accepted \\
\hline $\mathbf{H}_{3}$ & $\begin{array}{l}\text { The impact of price fairness on consumer loyalty is } \\
\text { positive }\end{array}$ & Accepted \\
\hline $\mathbf{H}_{\mathbf{4}}$ & $\begin{array}{l}\text { Information literacy moderates the relationship between } \\
\text { service quality and consumer loyalty }\end{array}$ & Accepted \\
\hline $\mathbf{H}_{5}$ & $\begin{array}{l}\text { Information literacy moderates the relationship between } \\
\text { price fairness and consumer loyalty }\end{array}$ & Accepted
\end{tabular}

\section{Conclusion}

This study attempts to analyze the impact of service quality and price fairness on consumer loyalty by moderating the role of information literacy. All operational top category food and beverage hotels existing in the hotel industry of Multan city were included as the population in the study. The data of 200 customers of hotels in Multan city were collected by using a convenient sampling technique. Partial least square (PLS) is used to estimate the results. Confirmatory analysis found that all the measures use to check the reliability and validity of data has fulfilled the threshold, it is concluded that the data used in a study is highly reliable. Correlation analysis shows that consumer loyalty is positively correlated with service quality, information literacy, and price fairness. PLS estimates explore that the variables service quality, price fairness, and information literacy are positively and significantly related to consumer loyalty. The outcomes of the moderated regression show that information literacy positively moderates the relationship between service quality and consumer loyalty as the association is found to be statistically significant. On the contrary, the variable information literacy negatively moderates the relationship between price fairness and consumer loyalty as the association is found to be statistically significant. All hypotheses of the study are accepted from the analysis and found that price fairness and service quality positively affect consumer loyalty in Pakistan. Therefore, managers of the hotel should focus on service quality and price fairness. Just price may increase the sales and loyalty of customers.

\section{Managerial Implications}

The outcomes of the study have added to the body of knowledge on customer loyalty by emphasizing the importance of service quality and price fairness as the primary predictors of customer loyalty in the Pakistani hotel industry. Information literacy was also found to be a major mediator between service quality and consumer loyalty, as well as price fairness and consumer loyalty, in the study.

This research has a number of managerial implications. The study's findings will give solid foundations for practitioners, particularly hotel managers in Pakistan, to develop and implement loyalty initiatives. Despite this, the most important indicator of customer loyalty is service quality. Similarly, research found that price fairness has a significant impact on consumer loyalty. Given the foregoing facts, hotel management must take efforts to improve service quality in order to promote customer loyalty. They will be able to capture the biggest proportion of the market in this way. The study's findings assist the hotel sector in focusing more on research progress in order to improve service quality and customer loyalty by viewing it as a hotel management goal. 


\section{Limitations of the Study}

Despite of the significant contribution of the study addressed in earlier section, there are some limitations of the current study. This data used in a study was only limited to customers of top-class outlets with a sample size of 200 respondents in Multan city. Further studies can also expand the sample size and can use the data from other cities of Punjab. On the contrary consumer loyalty affected by many other factors further studies can also be conducted and may use predictors and mediator variables such as satisfaction, trust, and revisit intonation etc.

\section{Recommendations}

To improve the service quality and boost the hotel industry in Pakistan following suggestions are recommended:

1. Managers of hotels must invest and improve the quality of service. Frequent surveys can also be conducted to assess the perceptions and suggestions of customers to improve service quality.

2. From the bottom to the top of their organization, managers must keep control of all actions linked to the idea of quality. Furthermore, leaders must treat their consumers with admiration and complete consideration to comprehend their expectations and experiences and to prevent conflict between them, which may improve customer loyalty.

3. Managers must enhance employee understanding of the idea of service quality since employees are responsible for dealing with customers and have direct contact with them.

4. Advertisement strategies may also be used to increase the sale of hotels. As information literacy is found to be the positive factor of consumer loyalty so that information about the products and services of hotels can also increase the loyalty of customers.

It is critical to innovate services in response to the requirements and wants of customers. Every approach must be centered on the customer. Hotel management must consider the ultimate consequence of their service quality improvements in this respect. Rather than focusing on the immediate issue, the attention should be on the long term.

\section{References}

Ajmal, H., Khan, R. A., \& Fatima, M. (2018). Impact of service quality on customer satisfaction in banking industry of Pakistan: A case study of Karachi. Journal of Social and Administrative sciences, 5(3), 219-238.

Bawden, D. (2001). Information and digital literacies: a review of concepts. Journal of documentation. 57.2: 218-259.

Bei, L. T., \& Chiao, Y. C. (2001). An integrated model for the effects of perceived product, perceived service quality, and perceived price fairness on consumer satisfaction and loyalty. Journal of consumer satisfaction, dissatisfaction and complaining behavior, 14, 125.

Cakici, A. C., Akgunduz, Y., \& Yildirim, O. (2019). The impact of perceived price justice and satisfaction on loyalty: the mediating effect of revisit intention. Tourism Review. 74(3), 443-462.

Cronin Jr, J. J., \& Taylor, S. A. (1992). Measuring service quality: a reexamination and extension. Journal of marketing, 56(3), 55-68.

Darke, P. R., \& Dahl, D. W. (2003). Fairness and discounts: The subjective value of a bargain. Journal of Consumer psychology, 13(3), 328-338.

Dehghan, A., \& Shahin, A. (2011). Customer loyalty assessment: A case study in MADDIRAN, the distributor of LG Electronics in Iran. Business Management and Strategy, 2(1), 1.

Donnelly, M. (2009). Building customer sense of fulfillment: A customer experience based approach in a tourism context. Bachelor of Business Studies in Marketing, (June), 205-212.

Dubey, A., \& Srivastava, A. K. (2016). Impact of service quality on customer loyalty-A study on telecom sector in India. IOSR Journal of Business and Management (IOSR-JBM), 18(2), 45-55.

Fida, B. A., Ahmed, U., Al-Balushi, Y., \& Singh, D. (2020). Impact of Service Quality on Customer Loyalty and Customer Satisfaction in Islamic Banks in the Sultanate of Oman. SAGE Open, 10(2).

Firend, A. R., \& Abadi, M. F. (2014). Impact of service quality, trust and perceived value on customer loyalty in Malaysia services industries. Procedia-Social and Behavioral Sciences, 164, 298-304. 
Fornell, C.G. and Larcker, D.F. (1981), "Evaluating structural equation models with unobservable variables and measurement error", Journal of Marketing Research, Vol. 18 No. 1, pp. 39-50.

Grönroos, C. (2004). The relationship marketing process: communication, interaction, dialogue, value. Journal of Business \& Industrial Marketing, 19(2), 99-113.

Hair, J. F., Ringle, C. M., \& Sarstedt, M. (2011). PLS-SEM: Indeed a silver bullet. Journal of Marketing theory and Practice, 19(2), 139-152.

Joudeh, J. M., \& Dandis, A. (2018). Service Quality, Customer Satisfaction and Loyalty in an Internet Service Providers. International Journal of Business and Management, 13(8), 108-120.

Kheng, L. L., Mahamad, O., \& Ramayah, T. (2010). The impact of service quality on customer loyalty: A study of banks in Penang, Malaysia. International journal of marketing studies, 2(2), 57.

Konuk, F. A. (2018). Price fairness, satisfaction, and trust as antecedents of purchase intentions towards organic food. Journal of Consumer Behaviour, 17(2), 141-148.

Kotler, P., Armstrong, G., Ang, S. H., Leong, S. M., Tan, C. T., \& Ho-Ming, O. (2012). Principles of marketing: an Asian perspective. Pearson/Prentice-Hall.

Kumar, A. (2017). Effect of service quality on customer loyalty and the mediating role of customer satisfaction: an empirical investigation for the telecom service industry. Journal of Management Research and Analysis, 4(4), 159-166.

Kumar, K., Rai, R. S., \& Dugar, A. (2019). Impact of service quality on customer satisfaction and loyalty in the sector of telecom service provider in Delhi-NCR. International Journal of Innovative Technology and Exploring Engineering, 8(8), 2278-3075.

Leinsle, P., Totzek, D., \& Schumann, J. H. (2018). How price fairness and fit affect customer tariff evaluations. Journal of Service Management. 13(1), 62-94.

Lovelock, C. and Wirtz, J. (2004). Services Marketing-People, Technology, Strategy. 5th edition. Prentice Hall.

Naik, C. K., Gantasala, S. B., \& Prabhakar, G. V. (2010). Service quality (SERVQUAL) and its effect on customer satisfaction in retailing. European journal of social sciences, 16(2), 231-243.

Nazari, M., Hosseini, M. A. S., \& Kalejahi, S. V. T. (2014). Impact of price fairness on price satisfaction, customer satisfaction and customer loyalty in iran telecommunication market (case: Mtn irancell company). Asian Journal of Research in Marketing, 3(1), 131-144.

Neal, W. D. (1999). Satisfaction is nice, but value drives loyalty. Marketing research, 11(1), 20.

Panda, T. K. (2003). Creating customer lifetime value through effective CRM in financial services industry. Journal of Services Research, 2(2), 157-171.

Parasuraman, A., Zeithaml, V. A., \& Berry, L. L. (1988). Servqual: A multiple-item scale for measuring consumer perc. Journal of retailing, 64(1), 12.

Pinto, M. (2010). Design of the IL-HUMASS survey on information literacy in higher education: A selfassessment approach. Journal of information science, 36(1), 86-103.

Poku, K., Zakari, M., \& Soali, A. (2013). Impact of service quality on customer loyalty in the hotel industry: An empirical study from Ghana. International Review of Management and Business Research, 2(2), 600-609.

Safi, K. U. (2018). Impact Of Perceived Service Quality On Customer Loyalty: Evidence From Casual Dining Restaurants Of Peshawar. City University Research Journal, 8(1).

Saleem, H., \& Raja, N. S. (2014). The impact of service quality on customer satisfaction, customer loyalty and brand image: Evidence from hotel industry of Pakistan. Middle-East Journal of Scientific Research, 19(5), 706-711.

Susanti, C. E. (2019). The Effect of Service Quality and Perceived Price Fairness on Consumer Loyalty through Consumer Satisfaction on Budget Hotel in East Java. The Effect of Service Quality and Perceived Price Fairness on Consumer Loyalty through Consumer Satisfaction on Budget Hotel in East Java, 12(6), 1-7.

Xia, L., Monroe, K. B., \& Cox, J. L. (2004). The price is unfair! A conceptual framework of price fairness perceptions. Journal of marketing, 68(4), 1-15. 
Yaqub, R. M. S., Halim, F., \& Shehzad, A. (2019). Effect of service quality, price fairness, justice with service recovery and relational bonds on customer loyalty: Mediating role of customer satisfaction. Pakistan Journal of Commerce and Social Sciences (PJCSS), 13(1), 62-94.

Yi, Y. (1990). A critical review of consumer satisfaction. Review of marketing, 4(1), 68-123. 